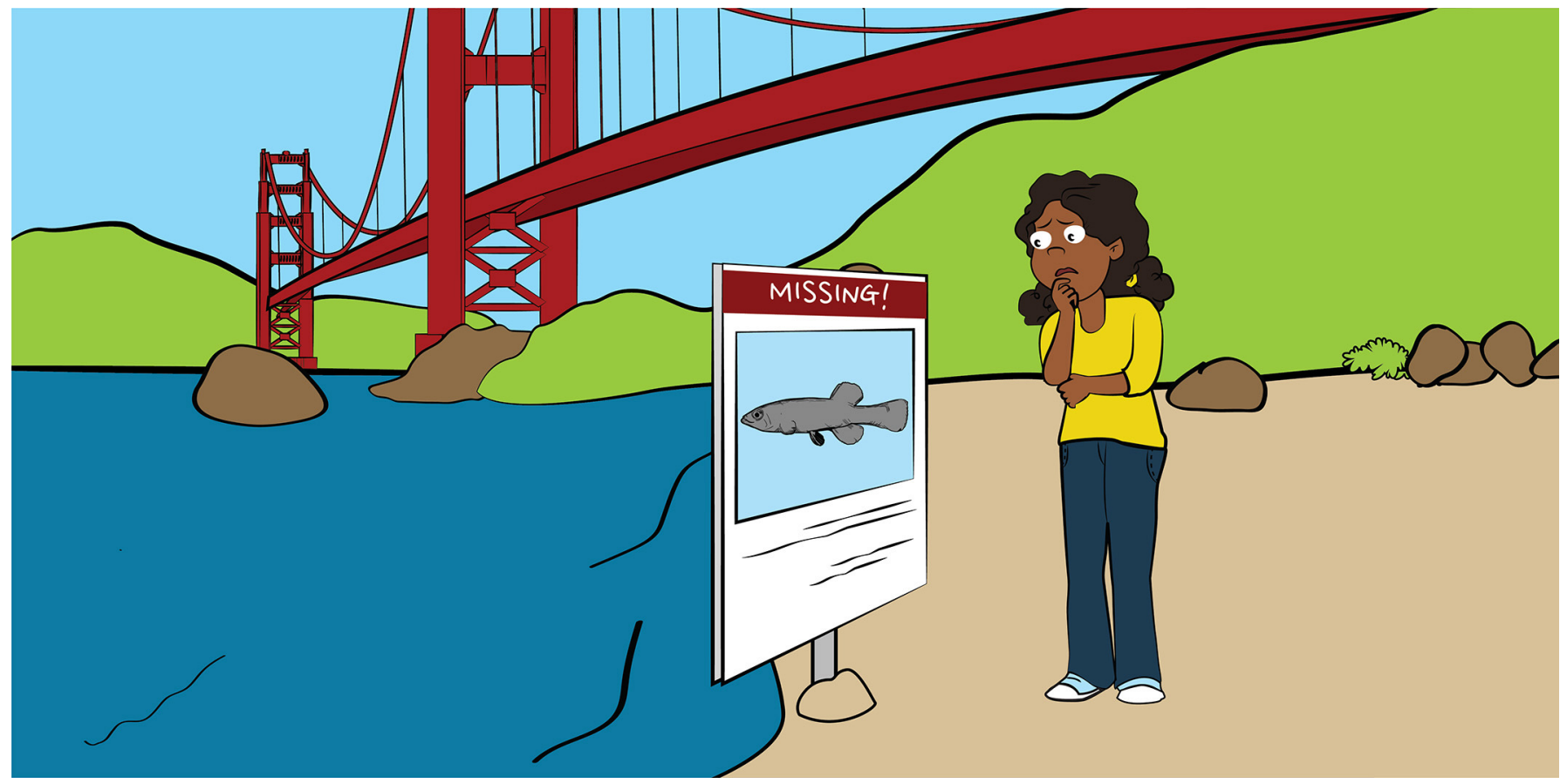

\title{
CRIME SCENE SAN FRANCISCO: WHO IS RESPONSIBLE FOR THE DISAPPEARANCE OF DELTA SMELT?
}

\section{Mallory E. Bedwell *, Craig Stuart and Melinda R. Baerwald}

California Department of Water Resources, West Sacramento, CA, United States

YOUNG REVIEWERS:

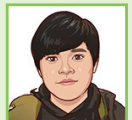

HUGO

AGE: 9

ITZAMNÁ

AGE: 8
Delta smelt are becoming harder and harder to find in the San Francisco Estuary. Some of the suspects in their disappearance are invasive fish species that were introduced from other places into the Estuary. These invasive fish can impact their new habitat by eating the native species that were originally there. However, it is hard to understand what the invasive fish are eating. We found that we can use the DNA in the stomachs of invasive fish to figure out what they have eaten. We caught a common invasive fish in the Estuary, called the Mississippi silverside, and analyzed the DNA from their stomachs to see if it matched delta smelt DNA. We discovered that some Mississippi silversides had delta smelt DNA in their stomachs! We therefore believe that Mississippi silversides are one of the culprits causing the disappearance of delta smelt. 


\section{ESTUARY}

The end portion where one or more freshwater rivers flow into the saltier ocean.

\section{INVASIVE SPECIES}

A species that has been moved from its original location and introduced into a new environment where it competes for resources with the species that normally live there.

\section{THE SCENE OF THE CRIME}

An estuary is the final section of one or more freshwater rivers before they meet the salty ocean. This mixing of salty and fresh water in estuaries creates unique environments, with varying degrees of saltiness, in which plants and animals can live. The San Francisco Estuary is the largest estuary on the west coast of the United States and it may contain more invasive species than most estuaries. Invasive species are species that have arrived in an environment from somewhere else and tend to take over their new environments [1]. While native species were once widespread, the Estuary is now home to many invasive species of fish, plants, clams, jellyfish, and plankton from all over the world. In the last few decades, tragedy has struck the Estuary. A once abundant and highly sensitive native fish species, the delta smelt, is mysteriously disappearing at an alarming rate [2]. Many years ago, millions of delta smelt swam freely throughout the delta region of the Estuary, a maze of channels formed where the Sacramento and San Joaquin rivers meet. In recent years, delta smelt have been hard to find. Scientists are on a mission to solve the case of the vanishing delta smelt.

\section{THE VICTIM'S PROFILE}

Delta smelt are a small species of fish that only live in the Estuary and nowhere else in the world. They are silver and gray in color, grow to about $5-7 \mathrm{~cm}$ as adults (Figure 1A), and smell like cucumbers. Delta smelt can live in aquatic habitats with varying levels of saltiness. This makes the Estuary the perfect home for them [2]. Delta smelt only live about 1-2 years and they are sensitive to environmental changes like drought and warm water temperature. Drought and warm water temperature are occurring more commonly in California due to climate change [3] and these conditions reduce the ability of the delta smelt to survive and to lay eggs [4]. The numbers of delta smelt have declined so much that they are now protected under both the United States Federal Endangered Species Act and the State of California Endangered Species Act [5].

\section{THE SUSPECTS}

Based on information scientists have collected, there are multiple suspects that could be responsible for the disappearance of delta smelt. Three of the primary suspects include: (1) invasive species that outcompete or eat delta smelt; (2) loss of or changes to the physical water bodies they inhabit that make it difficult for delta smelt to live in the estuary; and (3) extreme changes in environmental conditions, such as water temperature, salinity, and muddiness of the water. The environment in the Estuary is complex and has changed over time. Therefore, it is likely that all three of these suspects, and possibly 
Figure 1

(A) The missing delta smelt and (B) the suspected Mississippi silverside.

\section{LARVAL}

An early form of any animal that sometimes looks very different from the juvenile or adult stages.
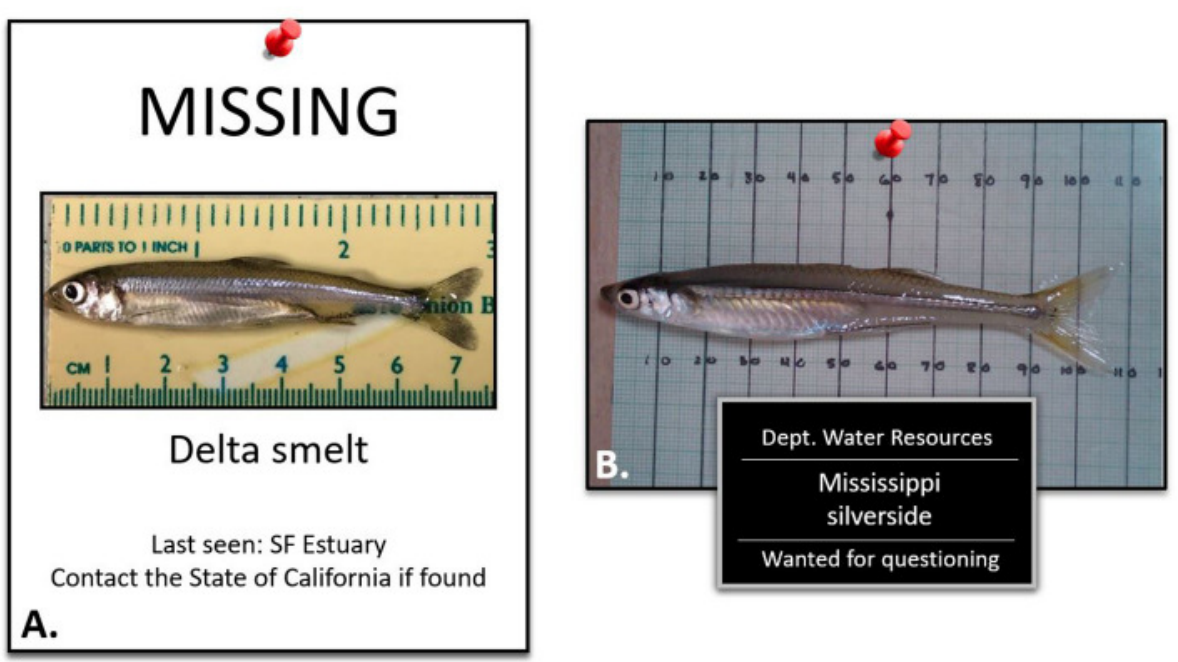

Figure 1

many others, have contributed to the disappearance of delta smelt. This investigation will focus on the first suspect: invasive species that outcompete or eat delta smelt.

\section{INVESTIGATION OF THE CRIME SCENE}

First, we wanted to know which invasive species to question about the disappearing delta smelt. We quickly began to suspect the Mississippi silverside, an invasive fish whose introduction to the Estuary happened around the same time as the disappearance of delta smelt (Figure 1B). Oddly enough, delta smelt and Mississippi silversides are very similar in their appearance, size, habitat preference, and eating habits. However, since an adult fish cannot eat another fish of the same size, we think that the adult Mississippi silverside might be eating delta smelt when they are small larval fish, or when they are still eggs.

We needed a method to test if Mississippi silversides eat delta smelt in the Estuary. But how could the unidentifiable, digested stomach contents of Mississippi silversides tell us what they ate? One way to find or detect a species is to test for the presence of its DNA. DNA is the unique set of genetic codes that all living creatures have. Like all good detectives, we tried to solve our crime by finding evidence directly linking the suspect to the victim, such as the presence of the victim's DNA inside the suspect's stomach. To do this, we collected Mississippi silversides from two locations where delta smelt are known to live, in nearshore and mid-channel environments of the Sacramento River Deep Water Ship Channel (Figure 2). We then looked for delta smelt DNA in the stomachs of Mississippi silversides.

We collected Mississippi silversides in the Sacramento River Deep Water Ship Channel during early April, which is also the peak time when 
Figure 2

The scene of the crime, where we suspect Mississippi silversides may be eating delta smelt. If we zoom in on the state of California, USA, we can see the Delta in the upper part of the San Francisco Estuary (SFE) in the yellow-outlined box. If we zoom in further on the red box in the estuary, we see a satellite image of the Sacramento River Deep Water Ship Channel. Mississippi silversides were collected from two locations in the Ship Channel, using two different methods: nearshore, using a beach seine, and mid-channel, using a trawl from a boat (Trawl photo credit: California Department of Fish and Wildlife).

TRAWL

A method to catch fish that involves dragging a large net in the water behind a boat.

\section{BEACH SEINE}

A method to catch fish which uses a net strung between two poles that is dragged along the bottom of a water body.

\section{FLUOROPHORE}

A light attached to a DNA assay that glows when it finds a DNA match, alerting us to the presence of the DNA of the species we are looking for.

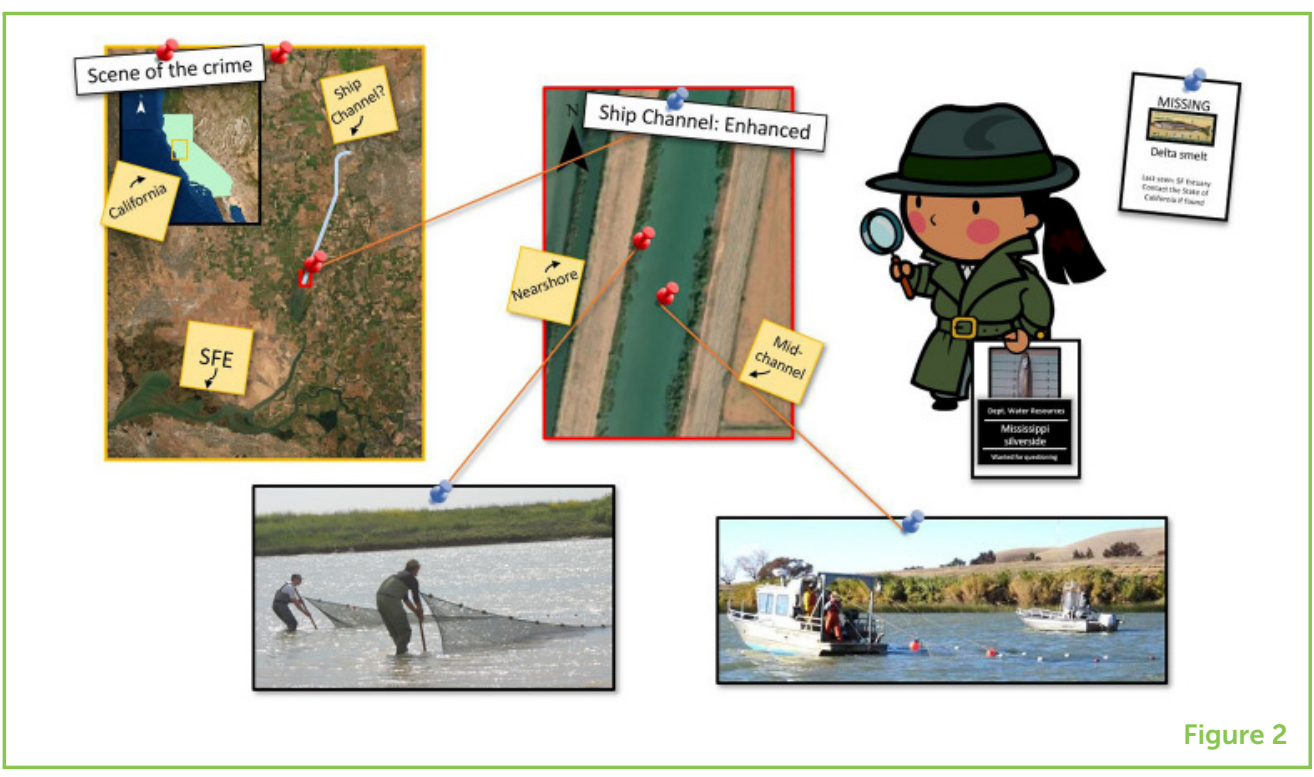

delta smelt lay their eggs. Fish in the mid-channel were captured using a trawl, which is a net dragged behind a boat. Nearshore fish were collected using a beach seine, which involves two people dragging a net along the bottom near the shore (Figure 2). The more Mississippi silversides that we captured, the greater the chance of detecting delta smelt DNA in their stomachs, and the stronger the evidence would be. We removed the stomach contents from all the Mississippi silversides we caught and extracted the DNA of the food in their stomachs. We used a method that breaks open the cells of the Mississippi silverside food so that we could release the DNA inside (Figure 3A).

We then used a DNA assay that could alert us to the presence of delta smelt DNA in the stomach contents of Mississippi silverside [6]. This assay is designed to match up, like a puzzle piece, with the unique DNA sequence of a delta smelt (Figure 3B). When the DNA in the assay matches with delta smelt DNA in the sample, a little fluorescent light on the assay, called a fluorophore, glows to indicate that a match was found (Figure $3 \mathrm{C}$ ). This means that if delta smelt DNA is present in the stomach sample, there will be a fluorescent signal. The absence of a fluorescent signal tells us that delta smelt DNA was not in the stomach of the Mississippi silversides, or was not eaten recently enough to be detected.

\section{INVESTIGATION RESULTS}

The investigators brought a total of 651 Mississippi silversides into the laboratory for intensive questioning (in this case, stomach dissections) related to the disappearance of delta smelt. Of the 651 suspects, 614 of them were collected from the nearshore habitat and 37 were collected from the mid-channel habitat. The suspects of the nearshore habitat were found innocent, having no detectable delta smelt DNA in their 
Figure 3

(A) Stomachs were removed from Mississippi silversides and DNA was extracted from the stomach contents. (B) Extracted DNA was tested using the delta smelt DNA assay. (C) If delta smelt DNA was present, the assay would bind to the DNA and the fluorophore in the assay would light up. (Fluorescence photo credit: New England Biolabs).

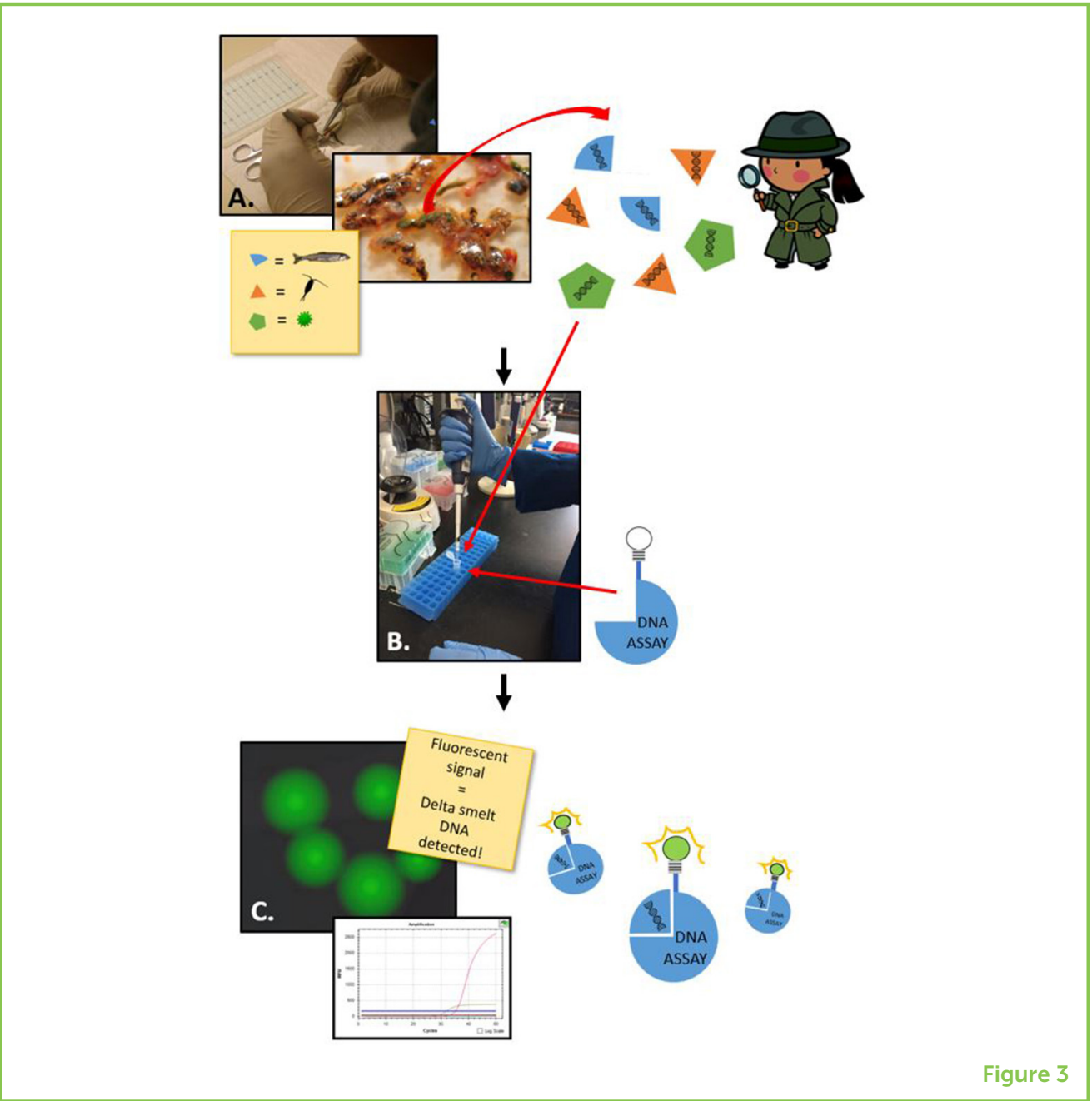

stomachs: all 614 suspects tested negative. For the suspects in the middle of the channel, almost half (41\%) tested positive for delta smelt DNA: 15 out of 37 Mississippi silversides were guilty and charged with eating delta smelt.

\section{CASE STILL OPEN}

The DNA results showed that Mississippi silversides do in fact eat smaller, younger delta smelt and could be a possible reason for the disappearance of this species. Because all Mississippi silversides containing delta smelt DNA came from the mid-channel of the Sacramento River Deep Water Ship Channel, we guessed that larval delta smelt prefer to spend their time in the middle of the channel. Delta smelt prefer to live in specific conditions, with cool temperatures and muddier water, which they may be more likely to find in the middle of the channel. Alternatively, it is possible the Mississippi silversides eat different prey in different parts of the channel. Mississippi silversides are also known to move to different areas during the day, to follow prey. It is possible the Mississippi silversides in the nearshore beach 
seine samples had not yet moved into the mid-channel to eat delta smelt. Importantly, DNA is only in the stomach until the predator finishes digesting and processing the meal. This means that delta smelt DNA would not be detected if a Mississippi silverside had eaten a delta smelt and then pooped it out before it was caught.

More detective work is needed to fully solve the mystery of the missing delta smelt. Researchers could look at how environmental factors affect when Mississippi silversides eat delta smelt. They could also use the DNA assay to see if other fish species are preying on delta smelt. Using DNA detection has allowed scientists to better understand which foods the fish in the estuary are eating and how diet preferences impact the abundance of native species. However, there are plenty of other major problems in the estuary that may contribute to the disappearance of delta smelt, so this important investigation will be long and complicated.

\section{ACKNOWLEDGMENTS}

We would like to thank the other original authors of this work: Brian Schreier, Gregg Schumer, and Bernie May. we would also like to thank the Interagency Ecological Program and the State and Federal Water Contractors Agency for their original funding of this project. Thank you to the young reviewers and their mentor for their suggestions and feedback.

\section{ORIGINAL SOURCE ARTICLE}

Baerwald, M. R., Schreier, B. M., Schumer, G., and May, B. 2012. Detection of threatened delta smelt in the gut contents of the invasive Mississippi silverside in the San Francisco Estuary using TaqMan assays. Trans Am Fish Soc. 141:1600-07. doi: 10.1080/000284 87.2012.717521

\section{REFERENCES}

1. Morais, P., Encarnação, J., Teodósio, M. A., and Dias, E. 2021. Aliens from an underwater world. Front Young Minds. 9:646539. doi: 10.3389/frym.2021.646539

2. Moyle, P. B., Brown, L. R., Durand, J. R., and Hobbs, J. A. 2016. Delta smelt: life history and decline of a once-abundant species in the San Francisco Estuary. San Franc Estuary Watershed Sci. 14:6. doi: 10.15447/sfews.2016v14iss2art6

3. Diffenbaugh, N. S., Swain D. L., and Touma, D. 2015. Anthropogenic warming has increased drought risk in California. Proc Nat Acad Sci USA. 112:3931-6. doi: $10.1073 /$ pnas.1422385112

4. Moyle, P. B., Herbold, B., Stevens, D. E., and Miller, L. W. 1992. Life history and status of Delta smelt in the Sacramento-San Joaquin Estuary, California. Trans Am Fish Soc. 121:67-77. 
5. Bennett, W. A. 2005. Critical assessment of the delta smelt population in the San Francisco Estuary, California. San Franc Estuary Watershed Sci. 3. doi: 10.15447/ sfews.2005v3iss2art1

6. Baerwald, M., Schumer, G., Schreier, B., and May, B. 2011. TaqMan assays for the genetic identification of delta smelt (Hypomesus transpacificus) and wakasagi smelt (Hypomesus nipponensis). Mol Ecol Resourc. 11:784. doi: 10.1111/ j.17550998.2011.03011.x

SUBMITTED: 30 September 2020; ACCEPTED: 01 December 2021; PUBLISHED ONLINE: 22 December 2021.

EDITED BY: Peggy W. Lehman, California Department of Water Resources, United States

CITATION: Bedwell ME, Stuart C and Baerwald MR (2021) Crime Scene San Francisco: Who Is Responsible for the Disappearance of Delta Smelt? Front. Young Minds 9:612548. doi: 10.3389/frym.2021.612548

CONFLICT OF INTEREST: The authors declare that the research was conducted in the absence of any commercial or financial relationships that could be construed as a potential conflict of interest.

COPYRIGHT @ 2021 Bedwell, Stuart and Baerwald. This is an open-access article distributed under the terms of the Creative Commons Attribution License (CC BY). The use, distribution or reproduction in other forums is permitted, provided the original author(s) and the copyright owner(s) are credited and that the original publication in this journal is cited, in accordance with accepted academic practice. No use, distribution or reproduction is permitted which does not comply with these terms.

\section{YOUNG REVIEWERS}
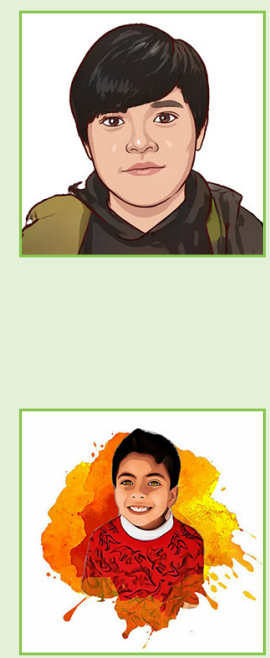

\section{HUGO, AGE: 9}

My name is Hugo, I am 9 years old and I am from Mexico City. My favorite hobbies are: playing video games, building with legos, listening music, and playing soccer. My favorite soccer team is "FC Barcelona" and I love to play goalkeeper. I enjoy drawing and seeing monuments, one of my biggest dreams is to travel around the world to see the most important monuments and buildings of each city. When I grow up I would like to be an architect or a professional soccer goalkeeper.

\section{ITZAMNÁ, AGE: 8}

Hi there! My name is Itzamná, it is a Mayan name. I love dinosaurs and e-games and I spend a lot of time playing Roblox or Minecraft. I have been camping since before I could walk, so I think I am a nature lover. I like science and enjoy each time I participate in scientific events for kids because I love to do experiments with plants' or animals' DNA. 

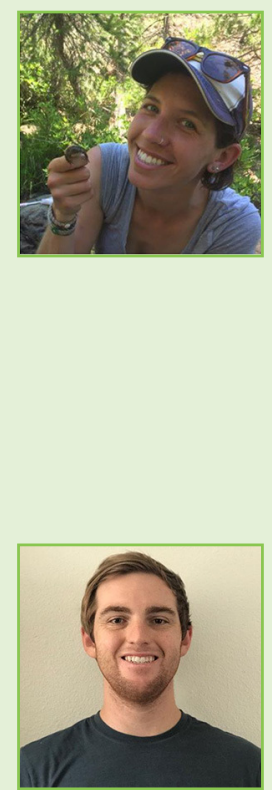

\section{MALLORY E. BEDWELL}

I am interested in using genetic techniques to help with management and conservation of species. In the past, I have studied how different species of amphibians have evolved. Most recently, I did research on how DNA released into the environment (called eDNA) from yellow-legged frogs can best be sampled to detect them in streams and lakes. At the California Department of Water Resources, I help collect samples that look at the overall state of the Yolo Bypass, including water quality, zooplankton, and fish. I plan on using eDNA monitoring techniques in the future to look for rare fish and to better understand zooplankton communities. *mallory.bedwell@water.ca.gov

\section{CRAIG STUART}

As a fish and wildlife scientific aid for the California Department of Water Resources, I have worked in Sacramento, CA researching aquatic ecology in the San Joaquin-Sacramento River Delta, specifically the Yolo Bypass floodplain. My work has mostly comprised of investigating the food web in the Yolo Bypass and understanding seasonal presence and abundance of native and non-native fish species, including Chinook salmon, delta smelt, and sturgeon. My interests include the conservation and habitat restoration of Chinook salmon and other fish species native to California. I began my Master of Environmental Science and Management degree from the University of California, Santa Barbara in fall of 2020.

\section{MELINDA R. BAERWALD}

Two things I feel passionate about are the conservation of threatened species and learning new things about our world through science. I am lucky because, in my job as an environmental program manager for the California Department of Water Resources, I get to do both! Most of my work is done as part of a team made up of scientists with different skill sets. I like to use genetic tools to understand aquatic species diversity, detect species even when you can not see them (using environmental DNA), and link important traits (migration, disease resistance, etc.) to underlying genetic variation. 